\title{
Önlisans Öğrencilerinin Depresyon ve Gündüz Uykululuk Düzeyi Bakımından İncelenmesi
}

\section{Examination of Depression And Daytime Sleepiness Level In Associate Degree Students}

\author{
Aysun Yağci Şentürk ${ }^{1 *}$, Elif Okur ${ }^{1}$ \\ ${ }^{1}$ Trabzon Üniversitesi, Tonya Meslek Yüksekokulu, Trabzon, Türkiye \\ e-mail: fzt.aysun.61@hotmail.com, elifcengiz_ec@hotmail.com \\ ORCID: 0000-0002-4802-3063 \\ ORCID: 0000-0003-2608-8584 \\ *Sorumlu yazar/ Corresponding Author: Aysun Yağci Şentürk \\ Gönderim Tarihi / Received: 06.08.2020 \\ Kabul Tarihi / Accepted: 18.10.2020 \\ DOI: $10.34087 /$ cbusbed.777565
}

Öz

Giriş ve Amaç: Önlisans öğrencilerinde depresyon ve gündüz uykululuk düzeyini belirlemek ve bunlara etki eden faktörleri ortaya koymak amaçlanmıştır.

Gereç ve Yöntemler: Araştırma sağlıkla ilgili programları içeren bir meslek yüksekokulunda 130 katılımcıyla yürütüldü. Veriler sosyo-demografik veri formu, Beck Depresyon Envanteri ve Epworth Uykululuk Ölçeği kullanılarak elde edildi. Veriler IBM SPSS Statistics 23,0 paket programı ile analiz edildi. Verilerin analizinde tanımlayıcı, parametrik ve nonparametrik testler ile korelasyon analizleri kullanıldı.

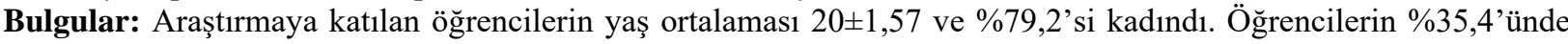
depresyon bulguları mevcutken, \%30'unda artmış gündüz uykululuğa rastlandı. Hem depresyon hem de artmış gündüz uykululuk oranı kadın öğrencilerde, erkek öğrencilerden anlamlı derecede yüksekti( $p<0,05)$. İlk ve acil yardım bölümünde okuyan öğrencilerde gündüz uykululuk düzeyi anlamlı derecede daha yüksekti(p<0,05). Vücut ağırlığı ve gündüz uykululuk düzeyi arasında negatif yönlü bir ilişki bulundu( $\mathrm{p}<0,05)$.

Sonuç: Depresyon ve artmış gündüz uykululuk düzeyinin önlisans öğrencilerinde yaygın olduğu ve birbiriyle ilişkili olduğu görüldü. Alınacak önlemlerle erken yaşlarda görülen depresyon ve artmış gündüz uykululuk düzeylerinde azalma sağlanmalıdır.

Anahtar kelimeler: Depresyon, Sağlık Meslek Okulu öğrencileri, Uyku.

\footnotetext{
Abstract

Objective: The aim of this study was to determine the level of depression and daytime sleepiness among associate degree students and to determine the factors affecting them.

Materials and Methods: The study was conducted with 130 participants at a vocational school of health. Data were obtained by using sociodemographic data form, Beck Depression Inventory and Epworth Sleepiness Scale. Data were analyzed with IBM SPSS Statistics 23.0 package program. Descriptive, parametric and nonparametric tests and correlation analyzes were used for data analysis.

Results: The mean age of the students was $20 \pm 1.57$ and $79.2 \%$ of them were female. Depression was present in $35.4 \%$ of the students and increased daytime sleepiness was found in $30 \%$ of the students. Both depression and increased daytime sleepiness were significantly higher in females than males $(p<0.05)$. The level of daytime sleepiness was significantly higher in the first and emergency aid students $(\mathrm{p}<0.05)$. A negative correlation was found between body weight and daytime sleepiness level $(\mathrm{p}<0.05)$.

Conclusion: It was seen, depression and increased daytime sleepiness were common in associate degree students and they were associated with eachother. Depression and increased daytime sleepiness which are seen at an early age should be decreased with the measures to be taken.
} 
Keywords: Depression, Health Occupations Students, Sleep.

\section{Giriş}

Ruhsal sağlık, duygu ve davranışların yanı sıra çevreyle uygun iletişim ve ilişki ağının sürdürülebilmesidir [1] Ruhsal sağlıkla ilgili dünya genelinde en sik karşılaşılan problem depresyondur ve Dünya Sağlık Örgütü (DSÖ) 2018 y1lı verilerine göre Dünya genelinde üç yüz milyon insanı etkilemektedir $[1,2]$. Depresyon; özgüven kaybı, suçluluk hissi, uyku, iştah ve konsantrasyon bozukluklarına neden olan ve genel hastalık yükünü arttıran bir durumdur [2]. Her yaşta görülebilmesine karşın, özellikle yaşamın ilk birkaç on yılı içinde görülme sıklığı daha fazladır $[3,4]$. Erken yaşlarda başlayan depresyon kronikleşerek ilerleyen yillarda mesleki ve psikososyal problemlere yol açabilmektedir [3, 4]. Yaş itibariyle depresyon yönünden risk altında olan gruplardan biri de üniversite öğrencileridir [5]. Üniversite yaşamı, ekonomik sorunlar, aileden ayrılmış olmak, kaldığı yere (ev ya da yurt) alışamamak ve arkadaşlık kuramamak gençlerde kaygı ve stresin açığa çıkmasına yol açmaktadır $[6,7]$. Artan kayg1 ve stres, depresyonu tetiklerken, gençlerde uyku kalitesinin azalmasina ve uyku ile ilgili bozuklukların ortaya çıkmasına yol açmaktadır [8].

Vücudu yaşama yeniden hazırlayan aktif bir yenilenme dönemi olan uyku, sağlıklı bir yaşamın devamı için önemli bir unsurdur ve fiziksel gelişim ile akademik performansın artırılmasında etkilidir [9-11]. Uyku ile ilgili bozuklukların, çocuk ve ergenlerde dikkati azalttığ1 ve gündüz uykululuk düzeyini $\operatorname{arttırdığ1~}$ yapılan çalışmalarla ortaya konmuştur [12]. Uyanık kalma girişimlerine rağmen gündüz uykuya dalma eğilimi olarak bilinen gündüz aşırı uykululuk, doğurduğu bireysel ve toplumsal olumsuz etkiler nedeniyle dikkat çeken bir kavramdır [13, 14]. Amerika' da yaklaşık on altı bin birey üzerinde yapılan bir araştırmada gündüz uykululuk oranı \%8,7 olarak bulunurken, oranın gençler arasında daha fazla olduğu bildirilmiştir [15]. Gündüz uykululuk düzeyinin yüksek olması; yaşamı tehdit eden kazalara, iş verimliliğinde ciddi kayıplara, akademik performansta azalmaya ve psikososyal işlevlerde bozukluklara neden olmaktadır. Bunun yanı s1ra obezite, diyabet ya da depresyon varlığ1 gündüz uykululuk oranının artışında rol oynamaktadir [16, 17].

Tüm bu nedenler göz önüne alındığında üniversite öğrencilerinin, depresyon ve artmış gündüz uykululuk bakımından yüksek risk altında olduğu görülmektedir. $\mathrm{Bu}$ doğrultuda planlanan araştırmada önlisans öğrencilerinin, depresyon ve gündüz uykululuk düzeyini incelemek ve bunlara etki eden faktörleri belirlemek amaçlanmıştır.

\section{Materyal ve Metot}

\subsection{Araştırmanın Dizaynı}

Kesitsel tipte planlanan araştırma, bir meslek yüksekokulunda okuyan öğrenciler üzerinde gerçekleştirildi. Araştırma evrenini, aktif olarak öğrenci alan Yaşlı Bakımı, Fizyoterapi ve İlk ve acil yardım programlarında öğrenim gören toplam 240 öğrenci oluşturdu. Araştırmanın örneklem seçiminde evrenin tamamına ulaşılması hedeflendi. Aralık 2019Şubat 2020 tarihleri arasında aktif olarak öğrenime devam eden, sözel iletişim kurulabilen, görme ve işitme kaybı olmayan, araştırmaya katılmayı kabul eden ve tüm bilgileri eksiksiz dolduran 130 öğrenci araştırmaya dahil edildi. Araştırma kapsamında öğrencilere iki ayrı bölümden oluşan formlar uygulandı. Birinci bölüm, öğrencilerin sosyodemografik özelliklerini belirlemeye yönelik sorulardan meydana gelmekteydi. İkinci bölümde ise; gündüz uykululuk düzeyini belirlemeye yönelik Epworth Uykululuk Ölçeği (EUÖ) ve depresyon durumunu belirlemeye yönelik BECK Depresyon Envanteri (BDE) öğrencilere uygulandı.

\section{2. Ölçekler}

BDE, kişinin son bir hafta içinde kendini nasıl hissettiğiyle ilgili sorular soran ve depresyon durumunu ortaya koymayı amaçlayan bir ölçektir [18]. Yirmi bir sorudan oluşan ölçeğin her bir sorusu 0 ile 3 puan arasında bir değer almaktadır. Ölçeğin toplam puanı 0 ile 63 puan arasında değişmektedir. Toplam puanın "09" arasında olması minimal derecede depresyonu, "1016 puan" hafif derecede depresyonu, "17-29 puan" orta derecede depresyonu ve "30-63 puan" ise ciddi derecede depresyonu ifade eder [18]. Üniversite öğrencileri üzerinde Türkçe geçerlik ve güvenirliği yapılan ölçeğin kesme (cut-off) puanları incelenmiş, 17 puan ve üzerinin depresyonu \%90'ın üzerinde bir doğrulukla ayırt edebildiği bildirilmiştir [19].

Gündüz uykululuk durumu için kullanılan EUÖ ise subjektif ölçüme dayalı ve kolayca uygulanabilen bir ölçektir [19]. Gün içindeki 8 farklı aktivite durumunda uyuklama veya uykuya dalma eğilimini değerlendirmeyi amaçlar. Ölçeğin Türkçe geçerliği ve güvenirliği 2008 yılında yapılmıştır [20]. Sekiz maddeden oluşan ölçeğin her bir maddesi 0 ile 3 puan arasında derecelendirilmiştir. Ölçekten elde edilen toplam puan en az 0 'ken, en çok 24 puandır. On puanın üstündeki değerler artmış gündüz uykululuk durumunu bildirmektedir [20].

Araştırma kapsamında, sosyodemografik veri formu ve ilgili ölçekler araştırmaya katılmayı kabul eden öğrenciler tarafından tek bir seferde dolduruldu. Veriler ders saati dışında kalan vakitlerde, sınıf ortamında elde edildi ve verilerin toplanması yaklaşık 15 dakika sürdü. 2.3. Veri analizi

İstatistiksel analizde IBM Statistical Package of Social Sciences (SPSS 23.0) yazılımı kullanıldı. Katılımcıların tanımlayıcı istatistikleri belirtilirken, kategorik değişkenler için yüzde ve frekans; sürekli değişkenler için ortalama, standart sapma, minimum ve maksimum değerler verildi. Verilerin analizinde Kruskal Wallis, Mann Whitney U, ANOVA, bağımsız t testi ile Pearson ve Spearman korelasyon analizleri kullanıldı. Sonuçlar \%95 güven aralığında $\mathrm{p}<0.05$ anlamlılık düzeyinde değerlendirildi.

\subsection{Etik konular}


Tablo 1. Öğrencilerin Tanıtıcı Özellikleri $(n=130)$



Araştırma için gerekli etik kurul izni, Karadeniz Teknik Üniversitesi Tıp Fakültesi Bilimsel Araştırmalar Etik Kurulu'ndan (etik kurul karar numarası: 24237859858)Araştırmanın amacı öğrencilere açıklanarak, öğrencilerden sözlü ve yazılı onam alındı.

\section{Bulgular}

Araştırmaya katılan öğrencilerin yaş ortalaması $20 \pm 1,57$, boy ortalamas $166,36 \pm 8,65$, kilo ortalamas 1 $62,71 \pm 11,48$ ve vücut kitle indeksi ortalamas1 $22,56 \pm 3,82$ 'dir. Katılımc1ların cinsiyet, vücut kitle indeksi ve okuduğu program dağılımı ile sigara kullanım durumlarına ilişkin sayısal veriler Tablo 1 'de görülmektedir.

Tablo 2'de öğrencilerin BDE'ye göre depresyon düzeylerinin ve toplam puan ortalamalarının dağılımı görülmektedir. Buna göre depresyon düzeyi öğrencilerin \%39,2'sinde hafifken, \%2,3'ünde ise

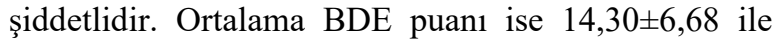
hafif depresyona işaret etmektedir (Tablo 2).

Tablo 3'te Öğrencilerin EUÖ düzeylerinin ve toplam puan ortalamalarının dağılımı verilmiştir. EUÖ toplam puanı 1 ile 24 arasında değişmekte olup, toplam puan ortalamas1 8,97 $\pm 4,08$ 'dir. Öğrencilerin \%30’unda gündüz uykululuk düzeyi artmıştır (Tablo 3 ).

Tablo 2. Öğrencilerin BECK Depresyon Envanteri’ne Göre Depresyon Düzeylerinin ve Toplam Puan Ortalamalarının Dağılımı (n=130)

\begin{tabular}{lcl}
\hline Depresyon Düzeyi & $\mathbf{n}$ & $\%$ \\
\hline Minimal Depresyon (0-9 arası) & 33 & 25,4 \\
Hafif Depresyon (10-16 arası) & 51 & 39,2 \\
Orta Depresyon (17-29 arası) & 43 & 33,1 \\
Şiddetli Depresyon (30-63arası) & 3 & 2,3 \\
\hline BECK Depresyon Envanteri Toplam Puanı & Min-Max & $\mathrm{X} \pm \mathrm{SS}$ \\
& $3-36$ & $14,30 \pm 6,68$ \\
\hline
\end{tabular}

Tablo 3. Öğrencilerin Epworth Uykululuk Ölçeği Düzeylerinin ve Toplam Puan Ortalamalarının Dağılımı (n=130)

\begin{tabular}{lll}
\hline Uykululuk Düzeyi & $\mathbf{n}$ & \% \\
\hline Normal (0-10) & 91 & 70 \\
Artmış Uykululuk (11-24) & 39 & 30 \\
& Min-Max & $\mathrm{X} \pm \mathrm{SS}$ \\
Epworth Uykululuk Ölçeği Toplam puan & $1-24$ & $8,97 \pm 4,08$
\end{tabular}


Tablo 4'te öğrencilerin tanıtıcı özelliklerine göre BDE puan ortalaması ile karşılaştırılması yer almaktadır. Yapılan korelasyon analizine göre yaş $(\mathrm{r}=-0,023$, $\mathrm{p}=0,795)$, boy $(\mathrm{r}=-0,134, \mathrm{p}=0,128)$, vücut ağırlığ $1(\mathrm{r}=$ $0,131, \mathrm{p}=0,138)$ ve VKİ $(\mathrm{r}=-0,066 \mathrm{p}=0,456)$ ile BDE puan ortalaması arasında istatistiksel olarak anlamlı bir ilişki bulunamadı ( $\mathrm{p}>0.05)$ (Tablo 4). Araştırmaya katılan kadın öğrencilerin BDE puan ortalamaları $(15,44 \pm 6,58)$ erkek öğrencilerin puanlarından daha yüksektir ve gruplar arasındaki fark istatistiksel olarak anlamlıdır $(\mathrm{p}<0.05)$. (Tablo 4). BDE puan ortalamaları birinci sinifta okuyan $(14,43 \pm 6,68)$, fizyoterapi programında öğrenim gören $(16,00 \pm 7,86)$, sigara kullanmayan $(14,44 \pm 6,93)$ ve obez olan öğrencilerde $(18,20 \pm 10,30)$ yüksek olmasina rağmen gruplar arasındaki fark istatistiksel olarak anlamlı değildir $(\mathrm{p}>0.05)$ (Tablo 4).

Tablo 4. Öğrencilerin Tanıtıcı Özelliklerine Göre BECK Depresyon Envanteri Puan Ortalamasının Karşılaştırılması

\begin{tabular}{|c|c|c|}
\hline Özellikler & $\mathbf{X} \pm \mathbf{S} . \mathbf{S}$ & Testler \\
\hline Yaş & & $\begin{array}{l}\mathrm{r}=-0,023 \\
\mathrm{p}=0,795^{*}\end{array}$ \\
\hline Boy & & $\begin{array}{l}r=-0,134 \\
p=0,128^{*}\end{array}$ \\
\hline Vücut ağırlığı & & $\begin{array}{l}\mathrm{r}=-0,131 \\
\mathrm{p}=0,138^{*}\end{array}$ \\
\hline VKİ & & $\begin{array}{l}r=-0,066 \\
p=0,456^{*}\end{array}$ \\
\hline $\begin{array}{l}\text { Cinsiyet** } \\
\text { Kadın } \\
\text { Erkek }\end{array}$ & $\begin{array}{l}15,44 \pm 6,58 \\
9,92 \pm 5,09 \\
\end{array}$ & $\begin{array}{l}\mathrm{t}=4,043 \\
\mathrm{p}=0,000\end{array}$ \\
\hline $\begin{array}{l}\text { Sinıf } * * * \\
1 . \sin \text { If } \\
2 . \text { sinıf }\end{array}$ & $\begin{array}{l}14,43 \pm 6,68 \\
13,14 \pm 6,73 \\
\end{array}$ & $\begin{array}{l}Z=-0,872 \\
p=0,383\end{array}$ \\
\hline $\begin{array}{l}\text { Program **** } \\
\text { İlk ve acil yardım } \\
\text { Yaşlı Bakım } \\
\text { Fizyoterapi }\end{array}$ & $\begin{array}{l}13,44 \pm 5,61 \\
13,86 \pm 6,50 \\
16,00 \pm 7,86 \\
\end{array}$ & $\begin{array}{l}\text { ANOVA }=1,548 \\
p=0,217\end{array}$ \\
\hline $\begin{array}{l}\text { Sigara Kullanma*** } \\
\text { Evet } \\
\text { Hayır }\end{array}$ & $\begin{array}{l}13,97 \pm 6,14 \\
14,44 \pm 6,93 \\
\end{array}$ & $\begin{array}{l}Z=-0,134 \\
p=0,894\end{array}$ \\
\hline $\begin{array}{l}\text { VKİ Sinıflandırma } * * * * * \\
<18,5 \text { Zayıf } \\
\text { 18,51-24,99 Normal } \\
25-29,99 \text { Fazla kilolu } \\
>30 \text { Obez }\end{array}$ & $\begin{array}{l}16,44 \pm 5,51 \\
13,95 \pm 6,93 \\
12,90 \pm 4,96 \\
18,20 \pm 10,30 \\
\end{array}$ & $\begin{array}{l}\mathrm{KW}=4,461 \\
\mathrm{p}=0,21\end{array}$ \\
\hline
\end{tabular}

*Sperman korelasyon testi $\mathrm{p}<0,05 * *$ Independent Simple t Testi ***Mann-whitney U testi ****ANOVA *****Kruskal Wallis

Tablo 5'te öğrencilerin tanıtıcı özelliklerine göre EUÖ puan ortalaması ile karşılaştırılması yer almaktadır. Yapılan korelasyon analizine göre öğrencilerin yaş $(\mathrm{r}=0,161, \mathrm{p}=0,067)$, boy $(\mathrm{r}=-0.17, \mathrm{p}=0,052)$ ve VKİ $(\mathrm{r}=-$ $0,129, p=0,143)$ ile EUÖ puan ortalaması arasında istatistiksel olarak anlamlı ilişki yoktur $(\mathrm{p}>0.05)$ (Tablo 5).

Korelasyon analizine göre öğrencilerin vücut ağırlığ ortalaması ile EUÖ puan ortalaması $(r=0,177, p=0,044)$ arasındaki fark istatistiksel olarak anlamlıdır $(\mathrm{p}<0.05)$ ve aralarında negatif yönde bir ilişki vardır. Buna göre vücut ağırlığı ortalaması arttıkça ile EUÖ puan ortalaması azalmaktadır (Tablo 5).
Araştırmaya alınan kadın öğrencilerin EUÖ puan ortalamaları $(9,38 \pm 4,27)$ erkek öğrencilerin ortalama puanlarından daha yüksektir ve gruplar arasındaki fark istatistiksel olarak anlamlıdır $(\mathrm{p}<0.05)$ (Tablo 5).

İlk ve acil yardım programında öğrenim görmekte olan öğrencilerin EUÖ puan ortalamaları $(10,05 \pm 4,50)$ diğer programlarda öğrenim gören öğrencilerin ortalama puanlarından daha yüksektir ve gruplar arasındaki fark istatistiksel olarak anlamlıdır $(\mathrm{p}<0.05)$ (Tablo 5).

EUÖ puan ortalamaları birinci sinifta okuyan $(8,98 \pm 4,20)$, sigara kullanan $(9,57 \pm 3,81)$ ve fazla kilolu olan öğrencilerde $(9,40 \pm 4,66)$ yüksek olmasına rağmen gruplar arasındaki fark istatistiksel olarak anlamlı değildir ( $\mathrm{p}>0.05$ ) (Tablo 5). 
Tablo 5. Öğrencilerin Tanıtıcı Özellikleri ile Epworth Uykululuk Ölçeği Puan Ortalamalarının Karşılaştırılması

\begin{tabular}{|c|c|c|}
\hline Özellikler & $\mathrm{X} \pm$ S.S & Testler \\
\hline Yaş & & $\begin{array}{l}r=-0,161 \\
p=0,067 *\end{array}$ \\
\hline Boy & & $\begin{array}{l}\mathrm{r}=-0,171 \\
\mathrm{p}=0,052 * *\end{array}$ \\
\hline Kilo & & $\begin{array}{l}\mathrm{r}=-0,177 \\
\mathrm{p}=0,044^{*}\end{array}$ \\
\hline VKİ & & $\begin{array}{l}r=-0,129 \\
p=0,143\end{array}$ \\
\hline $\begin{array}{l}\text { Cinsiyet**** } \\
\text { Kadın } \\
\text { Erkek } \\
\end{array}$ & $\begin{array}{l}9,38 \pm 4,27 \\
7,40 \pm 2,80 \\
\end{array}$ & $\begin{array}{l}Z=-2,306 \\
p=0,021\end{array}$ \\
\hline $\begin{array}{l}\text { Sinıf } * * * \\
1 . \text { sinıf } \\
\text { 2.sinıf }\end{array}$ & $\begin{array}{l}8,98 \pm 4,20 \\
8,92 \pm 2,97\end{array}$ & $\begin{array}{l}\mathrm{Z}=-0,177 \\
\mathrm{p}=0,859\end{array}$ \\
\hline $\begin{array}{l}\text { Program **** } \\
\text { İlk ve acil yardım } \\
\text { Yaşlı Bakım } \\
\text { Fizyoterapi }\end{array}$ & $\begin{array}{l}10,05 \pm 4,50 \\
7,93 \pm 3,45 \\
9,55 \pm 4,27 \\
\end{array}$ & $\begin{array}{l}\mathrm{KW}=7,371 \\
\mathrm{p}=0,025\end{array}$ \\
\hline $\begin{array}{l}\text { Sigara Kullanma*** } \\
\text { Evet } \\
\text { Hayır }\end{array}$ & $\begin{array}{l}9,57 \pm 3,81 \\
8,71 \pm 4,19\end{array}$ & $\begin{array}{r}\mathrm{Z}=-1,457 \\
\mathrm{p}=0,145\end{array}$ \\
\hline $\begin{array}{l}\text { VKİ Sınıflandırma } * * * * \\
<18,5 \text { Zayıf } \\
\text { 18,51-24,99 Normal } \\
\text { 25-29,99 Fazla kilolu } \\
>30 \text { Obez }\end{array}$ & $\begin{array}{l}9,11 \pm 3,56 \\
8,85 \pm 4,00 \\
9,40 \pm 4,66 \\
9,00 \pm 5,87\end{array}$ & $\begin{aligned} \mathrm{KW} & =5,635 \\
\mathrm{p} & =0,131\end{aligned}$ \\
\hline
\end{tabular}

Ayrıca öğrencilerin BDE ve EUÖ puanları arasındaki ilişki incelendiğinde her ikisi arasında pozitif yönde anlamlı bir ilişki olduğu bulundu $(\mathrm{r}=0.281, \mathrm{p}<0.01)$. Buna göre öğrencilerin BDE toplam puanı arttıkça, EUÖ toplam puanı da artmaktadir.

\section{Tartışma}

Gençlerde oluşabilecek uyku ve ruhsal bozukluklar ilerleyen yıllarda ortaya çıkabilecek pek çok sağlık sorununa zemin hazırlayabilmektedir. $\mathrm{Bu}$ nedenle erken yaşta depresyon ya da uyku sorunlarının tanınması ve tedavisinin sağlanması toplum sağlığına önemli bir katkı sağlayabilir. Araştırmamızda önlisans öğrencilerinde depresyon, gündüz uykululuk düzeyi ve bunlarla ilgili faktörleri ortaya koymaya çalıştık. Buna göre önlisans öğrencilerinde ortalama depresyon puanı $14,30 \pm 6,68$ olarak elde edildi. Türkiye'de depresyonun sorgulandığı araştırmalarda BDE ile hesaplanan ortalama puan; tıp fakültesi öğrencilerinde yaklaşık 10, hemşirelik öğrencilerinde 13 olarak bildirilmiştir [1, 22, 23]. Araştırmamıza benzer şekilde bir sağlik yüksekokulu öğrencilerindeyse ortalama BDE puanı 13,47+8,45 olarak bildirilmiştir [1]. Türk üniversite öğrencilerinde yapılan bu araştırmaları incelediğimizde, elde ettiğimiz ortalama BDE puanının literatürle tutarlı olduğu görülmektedir. Elde edilen BDE puanlarına göre öğrencilerde hafif düzeyde depresif semptomlar bulunmaktadır. BDE'nin kesme noktası göz önüne alındığında yaptığımız araştırmada öğrencilerin \%35,4'ünde depresyon bulguları mevcuttu. Farklı ülkelerdeki lisans öğrencilerinde yapılan araştırmalarda depresyon prevalansı Portekiz'de \%6,1, Amerika'da \%26, Kamerun'da $\% 30,6$ ve Suudi Arabistan'da \%55,9 olarak bildirilmiştir [24-27]. Oranlara bakıldığında bizim araştırmamızda bulunan depresyon oranı Suudi Arabistan dışındaki diğer ülke öğrencilerinden daha yüksektir. Ancak 2005 yılında Türk üniversite öğrencilerinde yapılan bir başka araştırmada bu oran \%26,2 olarak saptanmıştır [28]. Araştırmamızın önlisans öğrencileri üzerinde yürütülmesi, daha küçük bir örneklemde gerçekleştirilmesi, yerleşim yeri ve sosyo-kültürel faaliyet düzeyi gibi faktörlerin yüksek bir yüzde elde etmemize neden olduğunu düşünmekteyiz. Nitekim Türkiye'de tıp fakültesi öğrencileriyle sağlık yüksekokulu öğrencilerini depresyon yönünden kıyaslayan bir araştırmada sağlık yüksekokulu öğrencilerinin BDE puanı anlamlı derecede yüksek bulunmuştur [1].

Araştırmamızda elde edilen sosyodemografik verilerden yalnızca kadın ve erkekler arasında depresyon açısından anlamlı bir fark elde edildi. Buna göre kadınlarda depresif bulgular daha fazla görülmektedir $(15,44 \pm 6,58)$. Literatüre bakıldığında 
kadın öğrencilerde depresif bulguların daha fazla olduğunu belirten araştırmaların yanında, cinsiyetler arasında depresyon yönünden anlamlı bir fark olmadığını bildiren araştırmalar da mevcuttur [28, 29]. Depresyon ve uyku arasındaki ilişkiyi ortaya koyan pek çok araştırma literatürde mevcuttur [30, 31].Yapılan bir araştırmada, sabahları geç uyanıp ilerleyen saatlerde daha aktif olan öğrencilerin; erken uyanıp sabahları daha aktif olan ögrrencilere göre depresif belirti sıklığının daha fazla olduğu bildirilmektedir [32]. Yani uyku problemleri, psikolojik sorunların bir bulgusu olarak da ortaya çıkabilmektedir [33]. Bu bağlamda araştırmamızda depresyon ile gündüz uykululuk düzeyi arasında anlamlı bir ilişki olduğu saptandı. Öğrencilerin \%30'unda artmış gündüz uykululuk belirlendi. Demir, yaptığ 1 bir araştırmada hemşirelik öğrencilerinde gündüz uykululuk oranını $\% 10,5$ olarak bulurken, Ünal ve ark.' ları tıp fakültesi öğrencilerinde bu oranı \%15,4 olarak bulmuştur [22, 34]. Araştırmamızda kadın öğrencilerin gündüz uykululuk düzeyinin, erkek öğrencilerden daha yüksek olduğu belirlendi. Elde edilen sonuçlara göre hem depresyon hem de artmış gündüz uykululuk bakımından kadın öğrencilerin erkeklere oranla daha fazla risk altında olduğu görüldü. Ancak hesaplanan ortalama puanların yakınlığı dikkate alındığında erkek öğrenciler için de aynı risklerin göz önünde bulundurulması gerektiği saptandi.

Literatürde yapılan araştırmalarda sıklıkla obezite ile artmış gündüz uykululuk düzeyi arasındaki ilişki ortaya konmuş, ayrıca vücut ağırlığındaki artışın gündüz aşırı uykululuğu arttırdığı bildirilmiştir [35, 36]. Araştırmamızda obez öğrenci sayısının çok az $(n=5)$ olması obezite ve uykululuk düzeyi arasında ilişki bulunamamasının nedeni olarak düşünüldü. Vücut ağırlığı ile gündüz uykululuk düzeyi arasındaki negatif yönlü korelasyon ise elde ettiğimiz şaşırtıcı bir sonuçtu. Dolayısıyla bu sonucun raslantısal olup olmadığ yapılacak araştırmalarla irdelenmelidir.

İlk ve acil yardım programı öğrencilerinde gündüz uykululuk düzeyi, diğer programlarda okuyan öğrencilerden anlamlı derecede yüksekti. 2015 y1lında yayınlanan bir araştırmada vardiyalı çalışan sağlık elemanlarının \%83'ünde uyku kalitesinde azalma ve yarısında da artmış gündüz uykuluğa rastlanmıştır [37]. Dolayısıyla gelecekte vardiyalı çalışma ihtimali oldukça yüksek olan ilk ve acil yardım bölümü öğrencilerinde artmış gündüz uykululuk düzeyinin önemli bir sorun olma ihtimali göz önünde bulundurulmalıdır.

Yaptığımız araştırmada yaklaşık her 3 öğrenciden 1'inde artmış gündüz uykululuğa rastlandı. New York'ta yapılan bir araştırmada gündüz uykululuk düzeyi yüksek olan gençlerin, yetişkin dönemde daha fazla suç işleme eğiliminde olabileceği bildirilmiştir [38]. Bu doğrultuda üniversite öğrencilerinin artmış gündüz uykululuk düzeyi ve ilişkili olduğunu ortaya koyduğumuz depresyon düzeylerinde artış, bireysel ve toplumsal yönden pek çok olumsuz etki potansiyeline sahiptir.

\section{Sonuç}

Yaptığımız araştırmayla depresyon ve artmış gündüz uykululuğun önlisans öğrencilerinde yaygın olduğu ve birbiriyle ilişkili olduğu görüldü. Elde ettiğimiz sonuçların önlisans öğrencilerindeki mevcut durum hakkında fikir verdiğine inanıyoruz, ancak araştırmamızda evrende bulunan 240 öğrenciden ancak 130'u araştırmaya gönüllüydü. $\mathrm{Bu}$ nedenle Türkiye'deki profili yansitabilecek daha geniş kapsamlı araştırmaların yapılması gerektiği kanısındayız. Böylece erken yaşlarda depresyon ve artmış gündüz uykululuğa karşı oluşturulacak farkındalık ile gelecekte toplum sağlığına katkı sağlanacağına inanıyoruz.

\section{Referanslar}

1. Gültekin, B.K, Ruhsal bozuklukların önlenmesi: Kavramsal çerçeve ve sınıflandırma, Psikiyatride Güncel Yaklașımlar, 2010 , 2(4), 583-94.

2. Thapar, A, Collishaw, S, Pine, D.S, Thapar, A.K, Depression in adolescence, The Lancet, 2012,379(9820), 1056-67.

3. Bailey, A.P, Hetrick, S.E, Rosenbaum, S, Purcell, R, Parker, A.G, Treating depression with physical activity in adolescents and young adults: a systematic review and meta-analysis of randomised controlled trials, Psychological Medicine, 2017, 8(07), 1068-83.

4. Caspi, A, Elder, J.P, Bem, D.J, Moving away from the world: lifecourse patterns of shy children, Developmental Psychology, 1988, 24, 824-31.

5.Chen, L, Wang, L, Qiu, X.H, Yang, X.X, Qiao, Z.X, Yang, Y.J et al, Depression among Chinese university students: prevalence and socio-demographic correlates, Plos One, 2013. 8(3), e58379. doi: 10.1371/journal.pone.0058379.

6. Ulaş, B, Tatlibadem, B, Nazik, F, Sonmez, M, Uncu, F, Üniversite öğrencilerinde depresyon sıklığı ve ilişkili etmenler, Celal Bayar Üniversitesi Sağllk Bilimleri Enstitüsü Dergisi, 2016, 2(3), 75-71.

7.Ölçücü, B, Vatansever, Ş, Özcan, G, Çelik, A, Paktaş, Y, Üniversite öğrencilerinde fíziksel aktivite düzeyi ile depresyon ve anksiyete ilişkisi, Uluslararası Türk Eğitim Bilimleri Dergisi, 2015, 2015(4), 303-294

8. Önal Sahiner, G, Hisar, K.M, Üniversite Öğrencilerinde Uykusuzluk Şiddeti ve Depresyon Semptomları İlişkisi ve Depresyon Tedavisinin Uykusuzluk Şiddetine Etkisi, Gümüşhane Üniversitesi Sağlık Bilimleri Dergisi, 2018, 7.(1), 125-130.

9. Algın, D, Akdağ, G, Erdinç, O, Kaliteli uyku ve uyku bozuklukları, Osmangazi Tip Dergisi, 2016, 38(özel say1-1), 29-34.

10. Koulouglioti, C, Cole, R, Kitzman, H, Inadequate Sleep and Unintentional Injuries in Young Children, Public Health Nursing, 2008, 25(2), 106-14.

11. İyigün, G, Angın, E, Kırmızıgil, B, Öksüz, S, Özdil, A, Malkoç, M, Üniversite öğrencilerinde uyku kalitesinin mental sağlık, fiziksel sağlık ve yaşam kalitesi ile ilişkisi, Journal of Exercise Therapy and Rehabilitation, 2017, 4(3), 125-133.

12. Zhai, L, Zhang, H, Zhang, D, Sleep duration and depression among adults: A meta-analysis of prospective studies, Depression and anxiety, 2015, 32(9), 664-670.

13. Koçoğlu, D, Arslan, S, Lise Öğrencilerinde Gündüz Uykululuk Durumu ve İlişkili Faktörler. Hacettepe Üniversitesi Hemşirelik Fakültesi Dergisi, 2011, 18(1), 50-60.

14. Şenol, V, Soyuer, F, Akça, R, Argün, M, Adolesanlarda uyku kalitesi ve etkileyen faktörler, Kocatepe Tip Dergisi, 2012, 13(2), 104-93.

15. Bixler, E.O, Vgotzas, A.N, Lin, H.M, Calhoun, S.L, Vela-Bueno, A, Kales, A, Excessive daytime sleepiness in a general population sample: The role of sleep apnea, age, obesity, diabetes, and depression, Journal of Clinical Endocrinology \& Metabolism, 2005, 90, 4510-15.

16. Resta, O, Foschino-Barbaro, M.P, Legari, G, Talamo, S, Bonfitto, $\mathrm{P}$, Palumbo, A, et al, Sleep-related breathing disorders, loud snoring and excessive daytime sleepiness in obese subjects, International journal of obesity, 2001, 25(5), 668-69. 
17. Kara, B, Kilic, O, Predictors of poor sleep quality and excessive daytime sleepiness in Turkish adults with type 2 diabetes, Journal of Clinical Nursing, 2015,24(9-10),1436-1439.

18. Kapci, E.G, Uslu, R, Turkcapar, H, Karaoglan, A, Beck Depression Inventory II: evaluation of the psychometric properties and cut-off points in a Turkish adult population, Depression and Anxiety, 2008, 25(10), 104-10.

19. Hisli, N, A reliability and validity study of Beck Depression Inventory in a university student sample, The Journal of Psychology, 1989, 7,3-13.

20. Murray W.J, A New Method for Measuring Daytime Sleepiness: The Epworth Sleepiness Scale, Sleep, 1991, 14(6), 540-545.

21. İzci, B, Ardıç, S, Fırat, H, Sahin, A, Altınors, M, Karacan, I, Reliability and validity studies of the Turkish version of the Epworth Sleepiness Scale, Sleep Breathing, 2008, 12(2), 161-68.

22. Ünal, E, Aydın, R, Uzuner, G.T, Erdinç, O.O, Metintaş, S, Tıp fakültesi öğrencilerinde gündüz aşırı uykululuk hali ve depresyon şüphesi ilişkisi, Eskişehir Türk Dünyası Uygulama ve Araştırma Merkezi Halk Sağlı̆̆ı Dergisi, 2014, 1(1), 27-37.

23. Temel, E, Bahar, A, Çuhadar, D, Öğrenci hemşirelerin stresle baş etme tarzları ve depresyon düzeylerinin belirlenmesi, Fırat Sağlık Hizmetleri Dergisi, 2007, 2(5), 107-18.

24. Coentre, R, Faravelli, C, Figueira, M.L, Assessment of depression and suicidal behaviour among medical students in Portugal, International Journal of Medical Education, 2016, 7, 354-63.

25. Beiter, R, Nash, R, McCrady, M, Rhoades D, Linscomb M, Clarahan $\mathrm{M}$, et al, The prevalence and correlates of depression, anxiety, and stress in a sample of college students, Journal of Affective Disorders, 2015,173, 90-96.

26. Ngasa, S.N, Sama, C.B, Dzekem, B.S, Nforchu, K.N, Tindong, M, Arok,e D, et al, Prevalence and factors associated with depression among medical students in Cameroon: a cross-sectional study, BMC psychiatry, 2017, 17(1), 216.

27. Basudan, S, Binanzan, N, Alhassan, A, Depression, anxiety and stress in dental students, International journal of medical education, 2017, 8, 179-186.

28. Bostanc1, M, Özdel, O, Oguzhanoglu, N.K, Ozdel, L, Ergin, A, Ergin, N, et al. Depressive symptomatology among university students in Denizli, Turkey: Prevalence and sociodemographic correlates, Croatian Medical Journal, 2005, 46(1), 96-100.

29. Yaşar, A, Karaaslan, Ö, Yozgat ilinde bulunan obez çocuklarda depresyon ve yaşam kalitesinin değerlendirilmesi, Bozok Tlp Dergisi, 2018, 8(2), 42-46.

30. Demirci, K, Akgönül, M, Akpinar, A, Relationship of smartphone use severity with sleep quality, depression, and anxiety in university students, Journal of behavioral addictions, 2015, 4(2), 85-92.

31. Şenol, V, Soyuer, F, Akça, R, Argün, M, Adolesanlarda Uyku Kalitesi ve Etkileyen Faktörler, Kocatepe Tip Dergisi, 2012, 13(2), 104-93.

32. Medeiros, A.L.D, Mendes, D.B, Lima, P.F, Araujo, J.F, The relationships between sleep-wake cycle and academic performance in medical students, Biological Rhythm Research, 2001, 32(2), 263-70.

33. Morin CM, Jarrin DC. Epidemiology Of İnsomnia. Sleep Medicine Clinics, 2013;8(3):281-297.

34. Demir G. Daytime sleepiness and related factors in nursing students. Nurse Education Today. 2017;59:21-25.

35. Ng WL Orellana, L Shaw, JE, Wong E, Peeters, A. The relationship between weight change and daytime sleepiness: the Sleep Heart Health Study. Sleep medicine. 2017;36:109-18.

36. Mokhber, S, Ravanbakhsh PZ, Jesmi F, Pishgahroudsari M, Jolfaei AG, Pazouki A. Comparing the excessive daytime sleepiness of obese and non-obese patients. Iranian Red Crescent Medical Journal. 2016;18(7):e21964. doi:10.5812/ircmj.21964
37. Akram, JR, Alireza, C, Somayeh, D, Relationship between circadian rhythm amplitude and stability with sleep quality and sleepiness among shift nurses and health care workers, International Journal of Occupational Safety and Ergonomics, 2015, 21(3), 312-317.

38. Raine, A, Venables, PH, Adolescent daytime sleepiness as a risk factor for adult crime, Journal of Child Psychology and Psychiatry, 2017, 58(6), 728-735.

http://edergi.cbu.edu.tr/ojs/index.php/cbusbed isimli yazarın CBU-SBED başlıklı eseri bu Creative Commons Alıntı-Gayriticari4.0 Uluslararası Lisansı ile lisanslanmıştır.

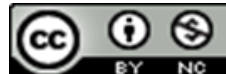

